\title{
Pengembangan "Perasaan Kita" sebagai Upaya Internalisasi Empati siswa SMP
}

\author{
(Developing "Our Feelings" as an Effort to Internalize Middle School Students' \\ Empathy)
}

\author{
Nanda Widya Muharammah*, Arbin Janu Setiyowati, Elia Flurentin \\ Universitas Negeri Malang, Jl. Semarang No. 5 Malang, Jawa Timur, Indonesia \\ *Penulis korespondensi, Surel: mnaya442394@gmail.com
}

Paper received: 11-Jan-2022; revised: 7-Feb-2022; accepted: 7-Feb-2022

\begin{abstract}
One of the factors that cause cases of aggression that occur among adolescents is the low level of individual empathy. This research and development aim to develop the "Perasaan Kita" media as a student tool in the internalization of empathy. "Perasaan Kita" is a media in interactive books by utilizing the QR code feature in its use. A guidebook for school counselors also accompanies this media to provide essential services in schools. The research method used is research and development using the Borg and Gall model, adapted according to the situation and field conditions. Test material experts, media experts, and potential users evaluate the acceptance of the developed media by looking at accuracy, usability, and convenience. The research instrument uses an expert and prospective user assessment format. The material and media expert test results were then analyzed using the analysis of the inter-rater agreement model, while the results of the prospective user test were analyzed using the numerical average. The test results show that the "Perasaan Kita" media gets a high score, so it can be interpreted that the "Perasaan Kita" media is an appropriate medium used by junior high school students to internalize empathy.
\end{abstract}

Keywords: empathy; "perasaan kita"; guidance

\begin{abstract}
Abstrak
Salah satu faktor penyebab kasus-kasus agresi yang terjadi di kalangan remaja adalah tingkat empati individu yang rendah. Penelitian dan pengembangan ini bertujuan untuk mengembangkan media "Perasaan Kita" sebagai upaya internalisasi empati siswa. "Perasaan Kita" merupakan media yang berwujud buku interaktif dengan memanfaatkan fitur QR code dalam penggunaannya, yang memenuhi kriteria akseptabilitas. Media ini juga disertai buku panduan bagi guru BK untuk memudahkan pemberian layanan dasar di sekolah. Metode penelitian yang digunakan yaitu research and development dengan menggunakan model Borg dan Gall yang telah diadaptasi sesuai dengan situasi dan kondisi lapangan. Uji ahli materi, ahli media dan calon pengguna memperhatikan keberterimaan media yang dikembangkan dengan melihat aspek ketepatan, kegunaan dan kemudahan. Instrumen penelitian menggunakan format penilaian ahli dan calon pengguna. Hasil dari uji ahli materi dan media kemudian dianalisis menggunakan analisis dari model kesepakatan interrater agreement sedangkan hasil uji calon pengguna dianalisis menggunakan rerata. Hasil uji menunjukkan bahwa media "Perasaan Kita" memperoleh nilai yang tinggi sehingga dapat diartikan bahwa media "Perasaan Kita" merupakan media yang sesuai untuk digunakan oleh siswa SMP dalam internalisasi empati.
\end{abstract}

Kata kunci: empati; "perasaan kita"; bimbingan

\section{Pendahuluan}

Dewasa ini semakin banyak kasus mencuat yang melibatkan empati remaja dalam hal mental health serta bullying. Salah satu kasus yang melibatkan empati dari siswa yaitu di SMP 16 Malang dimana seorang siswa mengalami perundungan. Tujuh orang siswa melempar, 
menduduki, dan juga menyiksa seorang korban (Antara, 2020). Kasus lainnya yaitu pada Minggu, 11 Juli 2021 mengenai seorang remaja berusia 14 tahun melakukan tindakan asusila kepada bocah 5 tahun di belakang rumahnya (Asri, 2021). Salah satu faktor penyebab kasuskasus agresi yang terjadi di kalangan remaja adalah tingkat empati individu yang rendah (Auliyah \& Flurentin, 2016).

Tendensi melakukan kekerasan terjadi karena rendahnya kemampuan seseorang untuk menempatkan dirinya pada posisi orang lain. Seseorang yang memiliki tingkat empati tinggi memiliki kecenderungan yang rendah dalam mempersulit orang lain, sehingga tidak akan terlibat dalam perilaku perundungan yang akan melukai atau membuat orang lain kesulitan (Andayani, 2012). Dalam perkembangan sosial yang baik, perlu adanya kemampuan menunjukkan respon yang tepat pada tiap kejadian yang dihadapi. Hal ini berkaitan dengan aspek kognitif serta afektif individu yang mana menurut merupakan dua aspek utama dalam empati (Davies, Stankov, \& Roberts, 1998). Empati adalah salah satu cara yang paling efektif dalam usaha memahami, mengenali dan mengevaluasi orang lain.

Minimnya kemampuan empati individu akan berdampak pada perilakunya dalam menghadapi suatu peristiwa dikarenakan kurangnya kemampuan untuk menempatkan dirinya pada posisi individu lain. Individu atau kelompok-kelompok yang terlibat perilaku agresif, sama sekali tidak memiliki rasa empati terhadap penderitaan yang dirasakan orang lain (Effendy \& Indrawati, 2020). Hal ini sejalan dengan penelitian lain yang menunjukkan bahwa pelaku perundungan melakukan perundungan karena memiliki kemampuan empati yang rendah (Rachmah, 2014).

Ketika seseorang dapat memposisikan dirinya sebagai orang yang menerima suatu perlakuan, hal itu akan meningkatkan kemampuan empati individu tersebut. Dengan memahami dan memiliki kemampuan empati, individu akan lebih memikirkan perasaan, pengalaman emosional serta dampak yang ditimbulkan dari aksinya. Proses empati digambarkan sebagai pengkondisian imajinasi dimana individu membayangkan dirinya berada pada posisi orang lain, kemudian seakan-akan ikut merasakan pengalaman tersebut yang berujung pada mengetahui tindakan tepat yang harus diambil.

Menunjukkan rasa empati tidak hanya ditunjukkan kepada korban, tetapi juga menjadi bentuk pencegahan konsekuensi negatif dalam diri korban (Bimantoko, Hawadini, \& Hartanti, 2020). Hal serupa juga ditunjukkan dalam penelitian lain, bahwa anak-anak yang cenderung mengekspresikan emosi yang serupa atau sama dalam kaitannya dengan pengalaman emosional orang lain memiliki kecenderungan yang kecil terhadap melakukan kekerasan pada anak-anak lainnya (Stavrinides, Paradisiotou, Tziogkouros, \& Lazarou, 2010). Perasaan positif, seperti empati memberikan kontribusi pada perkembangan moral remaja untuk menjadi lebih baik (Latifah \& Susanti, 2016).

Melatih kemampuan empati individu juga mampu meningkatkan kemampuan emosional yang dimiliki. Kemampuan emosional didefinisikan sebagai kemampuan untuk mengendalikan keinginan seseorang dan menunda pemenuhannya, untuk mengatur suasana hati orang lain, untuk mengisolasi perasaan dari berpikir, untuk menempatkan individu pada posisi orang lain (Davies et al., 1998). Kemampuan emosional melibatkan elemen-elemen kesadaran diri, empati, menangani hubungan, mengelola perasaan, motivasi (Goleman, 2020). 
Berdasarkan kajian tersebut, diketahui bahwa empati memiliki peran yang penting dalam mencegah perilaku agresif pada remaja. Empati sendiri merupakan aspek krusial dalam menjadikan individu seorang manusia seutuhnya. Hal ini dikarenakan dalam menjadi manusia perlu adanya kemampuan untuk merasa bersalah, menyesal, memahami perasaan orang lain serta mampu menempatkan dirinya di posisi orang lain (Keeran, 2014). Menipisnya empati pada generasi penerus menjadi salah satu tanggung jawab para orangtua, pendidik dan masyarakat sehingga diperlukan adanya tindakan preventif akan munculnya kasus-kasus serupa dikemudian hari.

"Perasaan Kita" merupakan media berupa buku yang akan menjelaskan, memberi contoh dan juga membantu siswa dalam menginternalisasi sikap empati dalam kehidupan sehari-hari. Dengan penggunaan yang mudah namun juga menarik, diharapkan media ini nantinya dapat berkontribusi dalam peningkatan sikap empati pada generasi muda. Media yang ditawarkan berbentuk buku berjudul "Perasaan Kita" yang berisikan mengenai penjelasan empati, lalu terdapat halaman berisikan macam-macam perasaan beserta penggambarannya. Kemudian terdapat tata cara menggunakan media, lalu dilanjut dengan gambar suatu karakter bernama disertai dengan $Q R$ Code dari video animasi cerita karakter tersebut untuk selanjutnya dapat siswa akses melalui handphone mereka, dan dibalik halaman dari tiap karakter terdapat tugas yang harus siswa kerjakan sebagai follow-up dari video dan materi yang telah diterima. Tidak hanya itu, terdapat lembar diskusi kelompok sebagai bentuk pemantapan materi yang telah siswa terima.

Media ini nantinya dapat digunakan guru BK sebagai media penyampaian layanan informasi untuk menumbuhkan sikap empati siswa yang mampu digunakan saat di kelas maupun bagi sekolah-sekolah yang tidak memiliki jam BK. Adanya instruksi di dalam media ini memungkinkan siswa untuk mengakses layanan secara mandiri sehingga dengan pengaplikasian yang mudah namun juga menarik, diharapkan media ini dapat menjadi alat bantu siswa dalam menumbuhkan sikap empati mereka.

Penelitian ini bertujuan mengembangkan media "Perasaan Kita" sebagai upaya internalisasi empati siswa yang memenuhi kriteria akseptabilitas: ketepatan, kegunaan, dan kemudahan. Dalam media ini terdapat produk berupa buku dan video untuk siswa serta buku panduan untuk guru BK sebagai pedoman dalam memberikan layanan bimbingan klasikal dengan menggunakan media "Perasaan Kita".

\section{Metode}

Penelitian ini menggunakan metode Research and Development (R\&D) dengan yang akan menghasilkan suatu produk yang layak dan menarik, serta lebih memungkinkan untuk diterapkan sebagai media layanan bimbingan. Penelitian dan pengembangan ini menggunakan model pengembangan dari Borg \& Gall (1983) dengan tahapan penelitian berupa: (1) research and information collecting, termasuk dalam langkah ini antara lain studi literatur yang berkaitan dengan kondisi empati siswa SMP, kemudian melakukan need assessment dengan teknik wawancara kepada guru BK dan persiapan untuk merumuskan kerangka kerja penelitian; (2) planning, dalam langkah ini merumuskan bentuk media serta format media yang sesuai bagi siswa SMP dalam internalisasi empati, kemudian menentukan tujuan yang akan dicapai pada setiap tahapan; (3) develop preliminary form of product, mengembangkan bentuk permulaan dari produk "Perasaan Kita". Termasuk dalam langkah ini adalah persiapan komponen pendukung, menyiapkan pedoman, dan melakukan evaluasi terhadap kelayakan 
alat-alat pendukung; (4) preliminary field testing, melakukan uji keberterimaan dengan melibatkan beberapa subjek penelitian berupa uji ahli materi, ahli media serta calon pengguna (guru BK). Pada langkah ini pengumpulan dan analisis data dilakukan dengan cara membagikan instrumen penilaian; (5) main product revision \& final product, pada tahap ini melakukan perbaikan terhadap produk awal yang dihasilkan berdasarkan hasil uji keberterimaan. Perbaikan ini dilakukan guna memperoleh draft produk (model) utama yang siap digunakan.

Penelitian ini bersubjek pada 1 ahli materi Bimbingan dan Konseling, 1 ahli media, serta 2 calon pengguna yang merupakan guru BK. Penilaian akseptabilitas produk dilakukan menggunakan instrumen berbentuk kuesioner yaitu kuesioner penilaian ahli materi, ahli media dan calon pengguna. Hasil dari penilaian ahli dan calon pengguna tersebut dianalisis menggunakan teknik analisis data inter-rater agreement yang digunakan pada hasil uji ahli materi dan media dan teknik analisis data numerik rerata yang digunakan pada hasil uji calon pengguna (guru BK).

\section{Hasil dan Pembahasan}

\subsection{Hasil}

Penelitian ini menghasilkan pengembangan media buku interaktif berjudul "Perasaan Kita". Dalam buku ini terdapat materi mengenai empati serta $Q R$ code yang mengarah pada video animasi yang dapat diakses siswa dengan mudah, serta buku panduan penggunaan media dalam setting layanan bimbingan klasikal bagi guru BK. Media ini dikembangkan dengan cara menggabungkan unsur konvensional media pembelajaran dengan keadaan di lapangan terkait revolusi industri 4.0 yang mengedepankan dunia digital dalam perilaku masyarakat. Media ini mencakup buku dengan konten terkait empati dan stimulasi kematangan emosi bagi siswa berupa video animasi. Cerita yang ditampilkan pada video animasi ini merupakan peristiwa yang dapat siswa temui sehari-hari sehingga memungkinkan mereka untuk memahami konteks cerita dan kaitannya dengan empati.

Pengembangan media ini menghasilkan dua video yang masing-masing dari video tersebut berfokus dalam internalisasi bagi siswa. Kedua video yang tercantum dalam media "Perasaan Kita" disusun dengan memperhatikan aspek-aspek empati menurut Davis (1980) yaitu aspek Perspective taking, fantasy, empathic concern dan personal distress. Video pertama berjudulkan Cerita Teman Sekelas dengan durasi 2 menit 40 detik. Video Cerita Teman Sekelas ini lebih berfokus pada pengambilan perspektif dari sudut orang lain atau perspective taking serta perasaan tidak nyaman ketika melihat ketidaknyamanan pada orang lain atau personal distress. Video animasi kedua dengan judul Cerita Ibu berdurasikan 3 menit 10 detik, menekankan aspek empati berupa fantasy atau memasuki suatu perasaan dari peristiwa yang tidak sedang individu alami dan rasa kepedulian individu pada orang lain yang ada di sekitarnya atau empathic concern.

Mempertimbangkan era yang tengah dihadapi saat ini, yaitu revolusi industri 4.0, pengembang memilih untuk mengembangkan media semi-digital agar dapat menarik minat siswa di era ini. Bagian digital dari media ini terletak pada bab berjudulkan Cerita Kita, dimana dalam bab ini akan menyediakan sebuah $Q R$ Code yang mengarahkan siswa pada sebuah video animasi yang dapat menstimulasi perasaan siswa dan membuat mereka terhanyut dalam kisah pihak lain tanpa harus secara langsung mengalami peristiwa tersebut. 
Media berupa video animasi dipilih agar dapat menstimulus siswa dengan visual juga audio sehingga pengalaman masuk ke dalam perasaan pihak lain dapat tertangkap lebih baik. Hal ini sejalan dengan pernyataan (Nimah, 2013). Video mampu merebut 94\% saluran masuknya pesan atau informasi kedalam jiwa manusia melalui mata dan telinga serta mampu membuat orang pada umumnya mengingat 50\% dari apa yang mereka lihat dan dengar dari tayangan program. Pengembangan media ini juga memperhatikan konten yang tepat dan berfokus pada tujuan utama agar tercipta proses belajar yang kondusif dan maksimal. Konten yang disajikan mengangkat perasaan yang mana memahami perasaan orang lain merupakan hal pokok dari terbentuknya empati pada diri seseorang. Hal ini sesuai dengan hakikat empati yang berupa respon emosional seseorang atas peristiwa yang dialami oleh pihak lain.

Secara keseluruhan, media "Perasaan Kita" merupakan media buku internalisasi empati bagi siswa yang di dalamnya mencakup pengertian singkat empati, visualisasi ragam perasaan, tata cara penggunaan media, $Q R$ code yang mengarah pada video animasi, lembar refleksi, dan lembar diskusi kelompok. Video animasi yang disajikan terdiri dari dua cerita yaitu cerita teman sekelas dan cerita ibu. Produk pendukung media ini berbentuk buku panduan bagi guru BK yang dicetak dengan ukuran A4. Dalam buku panduan ini terdapat penjelasan mengenai empati, media "Perasaan Kita" serta petunjuk penggunaan media dalam setting layanan bimbingan klasikal.

Secara teknis, pengimplementasian media "Perasaan Kita" dalam setting bimbingan klasikal diawali dengan pemberian pengantar berupa penjelasan empati oleh guru BK kemudian juga menjelaskan kaitannya dengan perasaan. Setelah itu, guru BK membagikan media buku "Perasaan Kita" kepada tiap siswa dan meminta mereka untuk mengisi biodata pada kolom yang telah disediakan. Selanjutnya, siswa diminta untuk membentuk grup terdiri dari 4-5 siswa lalu mempelajari materi di dalam buku kemudian mengakses video animasi sesuai dengan tata cara yang ada di dalam buku tersebut. Setelah itu, siswa diminta untuk menyelesaikan pertanyaan-pertanyaan pada lembar refleksi secara kelompok, yang diakhiri dengan presentasi hasil diskusi tiap kelompok.

Dalam tahapan penelitian dan pengembangan selanjutnya dilakukan uji yaitu uji ahli materi, media dan calon pengguna (guru BK). Dari hasil uji ahli materi diperoleh indeks validitas pada aspek ketepatan memperoleh sebesar 0,88, aspek kegunaan memperoleh sebesar 1,00, dan aspek kemudahan sebesar 0,87. Berdasarkan hasil uji ahli materi tersebut dapat dinyatakan bahwa materi yang disajikan pada "Perasaan Kita" merupakan materi yang sangat tepat, sangat berguna dan sangat mudah untuk digunakan dalam layanan bimbingan dan konseling. Data deskriptif yang didapatkan berupa pembenahan terkait penulisan materi pada buku panduan serta pemberian pengantar yang tepat disajikan pada tabel 1. Secara umum media telah layak untuk digunakan oleh siswa dalam internalisasi empati.

Tabel 1. Perbaikan Hasil Uji Materi

\begin{tabular}{lll}
\hline $\begin{array}{c}\text { Produk yang } \\
\text { direvisi }\end{array}$ & \multicolumn{1}{c}{ Sebelum } & \multicolumn{1}{c}{ Sesudah } \\
\hline $\begin{array}{l}\text { Panduan } \\
\text { konselor }\end{array}$ & $\begin{array}{l}\text { Terlalu banyak kata } \\
\text { "dalam" } \\
\text { Kutipan tetap dalam } \\
\text { bahasa Inggris } \\
\text { Tahapan awal tidak } \\
\text { ada yel-yel }\end{array}$ & $\begin{array}{l}\text { Meminimalisir penggunaan kata "dalam" } \\
\text { kutipan yang berbahasa inggris diubah ke bahasa } \\
\text { indonesia, kemudian diparafrase } \\
\text { Ditambahkan yel-yel untuk memberikan semangat } \\
\text { dalam melaksanakan bimbingan klasikal }\end{array}$ \\
\hline
\end{tabular}


Pada uji ahli media, "Perasaan Kita" memperoleh indeks validitas pada aspek ketepatan senilai 0,97, aspek kegunaan dan kemudahan media sebesar 1,00. Penilaian ini berarti media "Perasaan Kita" merupakan media yang sangat tepat, sangat berguna serta sangat mudah untuk digunakan karena indeks penilaian yang masuk dalam rentang nilai $0,76-1,00$. Data deskripsi yang diperoleh yaitu media sudah baik dengan aspek grafis yang cukup bagus sehingga media ini layak untuk digunakan. Salah satu masukan dari ahli media adalah perlu adanya pemberian judul media serta nama pengembang untuk menghindari adanya plagiasi. Masukan tersebut telah ditindaklanjuti dengan melakukan revisi seperti yang tersaji pada tabel 2 .

Tabel 2. Perbaikan Hasil Uji Media

\begin{tabular}{|c|c|c|}
\hline $\begin{array}{l}\text { Produk } \\
\text { yang } \\
\text { direvisi }\end{array}$ & Sebelum & Sesudah \\
\hline $\begin{array}{l}\text { Video } \\
\text { Cerita Kita }\end{array}$ & $\begin{array}{l}\text { Tidak ada judul media dan nama } \\
\text { pengembang }\end{array}$ & $\begin{array}{l}\text { Pemberian nama media di awal video } \\
\text { serta nama penyusun naskah dan } \\
\text { animator. } \\
\text { Perasaan Kita }\end{array}$ \\
\hline
\end{tabular}

Pada tahapan penelitian selanjutnya, dilakukan uji calon pengguna konselor dan siswa. Tujuan uji pengguna produk pengembangan adalah mengetahui respon atau penilaian subjek yang selanjutnya data digunakan untuk merevisi atau perbaikan produk penelitian (Sugiyono, 2015). Nilai media "Perasaan Kita" diperoleh dari hasil uji calon pengguna. Calon pengguna media "Perasaan Kita" merupakan dua guru BK yang sesuai dengan kriteria penelitian. Berdasarkan hasil uji calon pengguna ini, media "Perasaan Kita" memperoleh indeks validitas 1,00 pada aspek ketepatan, kegunaan dan kemudahan. Hal ini berarti keseluruhan media "Perasaan Kita" memiliki nilai keberterimaan yang sangat tinggi sehingga media ini sangat layak untuk digunakan dalam layanan bimbingan dan konseling siswa SMP.

\subsection{Pembahasan}

Menanggapi krisis empati yang tengah terjadi di kalangan generasi penerus, perlu adanya langkah pencegahan akan kondisi yang semakin buruk. Persoalan ini menjadi salah satu tanggung jawab guru BK untuk dapat membantu siswa mencapai perkembangan emosional serta moral yang baik. Hal ini sejalan dengan Standar Kompetensi Kemandirian Peserta Didik (SKKPD), dimana salah satu perkembangan aspek remaja yang harus terpenuhi adalah aspek kematangan emosi. Remaja sepatutnya memahami perasaan orang lain dan bertindak atas hal tersebut (Антипина \& Микляева, 2021). Memahami perasaan atau kondisi emosional orang lain artinya seseorang menggunakan kemampuan empati yang mereka miliki. 
Empati merupakan bagaimana seseorang memahami kerangka referensi internal orang lain secara akurat dan dengan komponen juga makna emosional yang berkaitan dengannya seolah-olah seseorang adalah orang lain, tetapi tanpa pernah kehilangan kondisi 'seolah-olah' (Tudor, 2011). Dengan kata lain, individu mampu merasakan sakit hati atau kesenangan yang dialami oleh orang lain tanpa pernah kehilangan pengakuan bahwa yang dirasakan adalah pengandaian. "Perasaan Kita" memungkinkan siswa untuk berlatih keadaan 'seolah-olah' dengan mudah dan terstruktur sehingga dapat pengalaman emosional orang lain.

Menurut Davis (1980), ada empat aspek dalam empati, yaitu: (1) perspective taking atau pengambilan perspektif dari sudut pandang orang lain, yang artinya adalah bagaimana individu memandang segala sesuatu dari sudut pandang dan perasaan orang lain; (2) fantasy yaitu bagaimana individu terhanyut dalam perasaan-perasaan yang ada di novel atau di film. Davis memandang bahwa empati juga ditunjukkan melalui kemampuan individu dalam memasuki suatu perasaan dari peristiwa yang tidak sedang individu tersebut alami; (3) empathic concern atau rasa kepedulian individu terhadap orang lain yang ada di lingkungan sekitarnya; (4) personal distress merupakan respon emosional tertentu, dimana individu merasa tidak nyaman dengan perasaannya sendiri ketika melihat ketidaknyamanan pada orang lain. Kaitannya dengan empati, individu perlu memahami konsep perasaan karena dengan memahami konsep perasaan, individu akan lebih mudah untuk menempatkan dirinya pada posisi orang lain dengan tepat, sehingga internalisasi empati dapat dilakukan dengan memahami perasaan orang lain atau melihat peristiwa dari sudut pandang orang lain. "Perasaan Kita" dirancang dengan memikirkan kemudahan siswa untuk memahami perspektif serta perasaan orang lain.

Perasaan adalah pengalaman fenomenal pribadi yang bersifat subjektif, evaluatif, dan tidak tergantung pada sensasi, pikiran, atau gambaran yang membangkitkannya. Perasaan pasti dievaluasi sebagai menyenangkan atau tidak menyenangkan, tetapi dapat memiliki kualitas intrapsikis yang lebih spesifik, sehingga, misalnya, nada afektif ketakutan yang dialami berbeda dari kemarahan. Karakteristik inti yang membedakan perasaan dari pengalaman intrapsikis kognitif, sensorik, atau perseptual adalah hubungan pengaruh dengan penilaian. Perasaan merupakan proyeksi mental individu dalam merespon suatu fenomena yang dialaminya. Perasaan bersifat subjektif (Akdoğan \& Çimşir, 2019), begitu pula dengan respon perasaan dari tiap individu bersifat berbeda dan bergantung pada kacamata individu tersebut yang menyebabkan perasaan bersifat subjektif. Hal ini berkaitan dengan empati yang menitikberatkan pada pemahaman akan pengalaman mental atau emosional individu lain dengan cara melihat suatu peristiwa menggunakan kacamata individu tersebut. Dalam menginternalisasi adanya empati dalam diri individu, perlu adanya pemahaman akan sudut pandang individu lain di berbagai macam setting fenomena.

"Perasaan Kita" merupakan media yang bertujuan sebagai alat bantu siswa dalam internalisasi empati. Media ini dirancang dengan mengedepankan penyampaian materi yang ringan serta mampu menarik minat siswa SMP. Dalam media ini terdapat materi empati, ragam perasaan, tata cara penggunaan media, $Q R$ code yang mengarah pada video animasi, lembar refleksi serta lembar diskusi kelompok siswa. Video animasi yang diangkat dalam media ini mengambil cerita yang dapat ditemui dalam kehidupan sehari-hari siswa. Video animasi yang pertama mengangkat cerita mengenai teman sebaya yang selalu diminta hasil pengerjaan tugasnya oleh teman lainnya. Video animasi kedua mengambil sudut pandang seorang ibu yang 
tengah sibuk beraktivitas mengerjakan pekerjaan rumah kemudian meminta tolong anaknya namun anaknya membentak.

Pemilihan media video animasi dilakukan untuk membantu siswa dalam menyerap materi lebih baik serta video animasi dipilih sebagai bentuk modeling simbolik yang akan membantu siswa dalam menerapkan materi yang diberikan. Teknik modeling simbolik adalah teknik yang dapat diimplementasikan oleh guru bimbingan dan konseling dalam memberikan layanan bimbingan dan konseling kepada siswa untuk mengembangkan potensi secara lebih optimal (Usman, Puluhulawa, \& Smith, 2017). Pemilihan teknik modeling simbolik dinilai sangat efektif untuk meningkatkan empati siswa SMP (Suhita, 2019). Teknik modeling simbolik dapat disajikan dalam berbagai bentuk seperti buku tertulis, film, maupun video animasi.

Adanya pengembangan media pembelajaran yang tepat akan membantu siswa untuk memperoleh materi dengan lebih baik. Pemakaian media pembelajaran dalam proses belajar mengajar dapat membangkitkan keinginan dan minat baru, membangkitkan motivasi dan rangsangan kegiatan belajar, memperjelas dan mempermudah konsep yang kompleks dan abstrak menjadi lebih sederhana, konkrit serta mempertinggi daya serap belajar siswa terhadap materi pembelajaran (Arsyad, 2016).

Media "Perasaan Kita" berbentuk buku interaktif yang memanfaatkan $Q R$ code dipilih demi meningkatkan minat siswa dalam mengikuti layanan secara maksimal. Berdasarkan penelitian yang dilakukan oleh Nurjanah (2018) menunjukkan bahwa minat baca tertinggi siswa terdapat pada ketika menemukan istilah yang sulit, siswa membaca kamus Bahasa Indonesia yang tersedia di perpustakaan tergolong dalam kategori "tinggi" dengan jumlah persentase sebesar 59.91\%. Dari penelitian tersebut menunjukkan bahwa siswa cenderung memiliki rasa keingintahuan yang tinggi terhadap hal yang belum diketahuinya.

Disamping media utama, terdapat pula media pendukung pelaksanaan layanan bimbingan dan konseling menggunakan media "Perasaan Kita" yaitu buku panduan bagi guru BK. Buku panduan ini disusun untuk membantu guru BK dalam memberikan layanan bimbingan dan konseling terkait empati kepada siswa SMP dengan menggunakan media "Perasaan Kita". Buku panduan disusun dengan memperhatikan waktu serta teknik yang sesuai bagi siswa SMP. Pemilihan teknik problem solving dilakukan demi membantu siswa meningkatkan kemampuan mereka dalam berfikir dan memecahkan masalah. Dalam penelitian yang dilakukan oleh Hamza dan Griffith (2006) dapat diketahui bahwa guru-guru menerapkan teknik pembelajaran berpikir kreatif dan memecahkan masalah akan membuat siswa belajar secara lebih terbuka, nyaman, menantang, aman, percaya diri, humoris, meningkatkan minat dan belajar kooperatif.

Keunggulan dari media "Perasaan Kita" yaitu adanya fitur $Q R$ code yang dapat meningkatkan minat siswa untuk mengikuti layanan secara maksimal. Hal ini berkaitan dengan perubahan zaman dan ditandai juga dengan perkembangan generasi yang ada. Dalam belajar, remaja cenderung menyukai hal-hal yang bersifat aplikatif dan menyenangkan. Mudahnya memperoleh informasi membuat generasi ini cepat bosan dalam menangkap pelajaran di sekolah yang disampaikan dengan cara konvensional. Inovasi dalam mengajar sangat diperlukan (Dewi, 2018; Koh \& Lee, 2019). Tidak hanya itu, adanya tata cara penggunaan di dalam buku memungkinkan siswa untuk menggunakan media ini secara mandiri. Hal ini tentunya akan sangat membantu bagi sekolah-sekolah yang tidak memiliki jam 
BK untuk tetap dapat membantu siswa dalam internalisasi empati dan menjadi pribadi yang lebih baik.

Dilihat dari hasil keseluruhan uji ahli materi, media serta calon pengguna, yang menunjukkan indeks validitas tinggi, dapat diketahui bahwa media "Perasaan Kita" merupakan media yang sangat tepat, sangat berguna dan sangat mudah untuk diimplementasikan dalam setting layanan bimbingan klasikal untuk membantu siswa menginternalisasi empati.

\section{Simpulan}

Pengembangan media "Perasaan Kita" sebagai upaya internalisasi empati siswa SMP telah memenuhi kriteria akseptabilitas meliputi aspek ketepatan, kegunaan dan kemudahan. Media "Perasaan Kita" memenuhi kriteria akseptabilitas dengan nilai validitas yang tinggi sehingga dapat dinyatakan sebagai media yang layak untuk diimplementasikan pada siswa SMP sebagai sarana internalisasi empati. Dengan pengaplikasian yang mudah memungkinkan media ini untuk diikuti oleh siswa dan juga guru BK sehingga dapat meminimalisir kesulitan pemberian layanan. Dalam penggunaan produk, saran bagi konselor yakni penggunaan produk ditujukan untuk konselor yang memiliki kualifikasi minimal S1 Bimbingan dan Konseling dan diharapkan memiliki pengetahuan yang memadai terkait empati sebelum memberikan layanan bimbingan kepada siswa, karena media "Perasaan Kita" hanya sebagai media penunjang dalam menampilkan materi dan menampilkan gambaran maupun ilustrasi mengenai pentingnya empati Untuk penelitian selanjutnya, pengembangan ini dapat dijadikan sebagai acuan dalam mengembangkan media-media layanan bimbingan dan konseling lainnya maupun penelitian lanjutan untuk melihat keefektifan media "Perasaan Kita" sebagai alat bantu siswa dalam internalisasi empati.

\section{Daftar Rujukan}

Akdoğan, R., \& Çimşir, E. (2019). Linking inferiority feelings to subjective happiness: Self-concealment and loneliness as serial mediators. Personality and Individual Differences, 149, 14-20. https://doi.org/10.1016/j.paid.2019.05.028

Andayani, T. R. (2012). Studi meta-analisis: Empati dan bullying. Buletin Psikologi, 20(1-2), 36-51.

Antara. (2020). Diduga Korban Bullying, Jari Siswa SMP di Malang Diamputasi. Retrieved from https://www.cnnindonesia.com/nasional/20200205140320-20-471871/diduga-korban-bullyingjari-siswa-smp-di-malang-diamputasi

Arsyad, A. (2016). Media pembelajaran. Bandung: Rajawali Press.

Asri, M. (2021). Remaja 14 Tahun "Preteli” Bocah 5 Tahun di Belakang Rumah, Pura-pura Ajak Adiknya Main.

Auliyah, A., \& Flurentin, E. (2016). Efektifitas Penggunaan Media Film untuk Meningkatkan Empati Siswa Kelas VII SMP. Jurnal Kajian Bimbingan Dan Konseling, 1(2), 19-26. https://doi.org/10.17977/um001v1i12016p019

Bimantoko, I., Hawadini, L., \& Hartanti, H. (2020). Efektivitas Pelatihan Empati Untuk Meningkatkan Perilaku Anti-Bullying Pada Siswa SMPN X Surabaya. RISTEKDIK: Jurnal Bimbingan Dan Konseling, 5(2), 132140.

Davies, M., Stankov, L., \& Roberts, R. D. (1998). Emotional intelligence: In search of an elusive construct. Journal of Personality and Social Psychology, 75(4), 989-1015. https://doi.org/10.1037/0022-3514.75.4.989

Davis, M. H. (1980). A multidimensional approach to individual differences in empathy.

Dewi, E. R. (2018). The effect of learning strategies, learning models, and learning innovation on educators' performance and education quality in senior high schools in Makassar. TEM Journal, 7(3), 548-555. https://doi.org/10.18421/TEM73-10 
Effendy, M., \& Indrawati, E. S. (2020). Hubungan Antara Empati Dengan Perilaku Agresif Pada Suporter Sepakbola Panser Biru Banyumanik Semarang. Jurnal Empati, 7(3), 974-984.

Goleman, D. (2020). Emotional intelligence. Bloomsbury Publishing.

Hamza, M. K., \& Griffith, K. G. (2006). Fostering problem-solving \& creative thinking in the classroom: cultivating a creative mind. National Forum of Applied Educational Research Journal-Electronic, 9(3), 132.

Keeran, D. (2014). Empathy Education: Becoming More Human.

Koh, E., \& Lee, S.-S. (2019). Learning innovations from research to practice: dilemmas in the field. Learning: Research and Practice, 5(1), 87-92. https://doi.org/10.1080/23735082.2019.1584449

Latifah, L., \& Susanti, R. H. (2016). Upaya meningkatkan empati siswa SMP Muhammadiyah 1 Malang melalui penggunaan teknik sinema terapi. JKI (Jurnal Konseling Indonesia), 1(2), 88-95.

Nimah, Z. (2013). Penggunaan Media Video Untuk Meningkatkan Pemahaman Shalat Fardlu Pada Siswa Kelas II MI Al-Mujahidin Gumalar Adiwerna Tegal. UIN Sunan Ampel Surabaya.

Nurjanah, N. (2018). Minat baca siswa di smp n 1 semanu kabupaten gunungkidul tahun 2018. Hanata Widya, $7(5), 71-82$.

Rachmah, D. N. (2014). Empati pada pelaku bullying. Jurnal Ecopsy, 1(2), 51-58.

Stavrinides, P., Paradisiotou, A., Tziogkouros, C., \& Lazarou, C. (2010). Prevalence of bullying among Cyprus elementary and high school students. International Journal of Violence and School, 11, 114-128.

Sugiyono. (2015). Metode Penelitian Pendidikan; Pendidikan Kuantitatif, Kualitatif, dan R\&D. Bandung: Alfabeta CV Bandung.

Suhita, R. D. (2019). Keefektifan teknik modeling simbolik untuk meningkatkan empati siswa kelas VII SMP Negeri 24 Malang. Universitas Negeri Malang.

Tudor, K. (2011). Understanding empathy. Transactional Analysis Journal, 41(1), 39-57.

Usman, I., Puluhulawa, M., \& Smith, M. Bin. (2017). Teknik Modeling Simbolis Dalam Layanan Bimbingan Dan Konseling. Proceeding Seminar Dan Lokakarya Nasional Bimbingan Dan Konseling 2017, 84-92.

Антипина, С. С., \& Микляева, А. В. (2021). Взаимосвязь склонности к киберагрессии, агрессивности и эмпатии в подростковом возрасте. Российский Психологический Журнал, 18(2), 94-108. https://doi.org/10.21702/rpj.2021.2.6 